TECHNICAL TRANSACTIONS 4/2017

CZASOPISMO TECHNICZNE 4/2017

ENVIRONMENTAL ENGINERING

DOI: $10.4467 / 2353737 X C T .17 .056 .6367$

Bartłomiej Macherzyński (bartlomiej.macherzynski@wp.pl)

Institute of Business Management, Faculty of Management, Częstochowa University of Technology

Maria Włodarczyk-Makuła (mwm@is.pcz.czest.pl)

Department of Chemistry, Water and Wastewater Technology, Faculty of Infrastructure and Environment, Częstochowa University of Technology

\title{
Ewa Ładyga
}

Institute of Mathematics, Faculty of Mechanical Engineering and Computer Science, Częstochowa University of Technology

\section{Władysław Pękała}

Department of Management Engineering, Faculty of Management, Częstochowa University of Technology

\section{COMPARISON OF PARAMETERS CO-FERMENTATION PROCESS}

OF MUNICIPAL SEWAGE SLUDGE WITH EXCESS SEWAGE SLUDGE

FROM TREATED COKING WASTEWATER

\section{PORÓWNANIE PARAMETRÓW PROCESU KOFERMENTACJI MIESZANINY OSADÓW KOMUNALNYCH Z NADMIERNYMI OSADAMI \\ Z OCZYSZCZANIA ŚCIEKÓW KOKSOWNICZYCH}

\begin{abstract}
The study presents results concerning changes of physicochemical properties and biogas production during the co-digestion process. The sample constituted a mixture of raw and excess sludge that was inoculated and fermented. The sample is the abovementioned mixture with an addition of excess sewage. In the assumed test, the conditions of technological parameters of sewage sludge fermentation and its mixtures with sewage sludge coke did not differ from each other by more than $25 \%$ Therefore, excess sewage sludge from treated coking wastewater can be neutralized in the process of fermentation along with municipal sewage sludge provided a constant quality-quantitative control of sewage sludge and procedural parameters.
\end{abstract}

Keywords: biogas, co-fermentation, sewage sludge, sewage sludge from treated coking wastewater

\section{Streszczenie}

W pracy przedstawiono wyniki badań dotyczące zmian wlaściwości fizyczno-chemicznych oraz produkcji biogazu podczas procesu kofermentacji. Próbkę kontrolną stanowily osady komunalne zaszczepione przefermentowanymi. Próbka badana to mieszanina komunalnych z dodatkiem nadmiernych osadów koksowniczych. W przyjętych warunkach badań wartości parametrów technologicznych fermentacji osadów komunalnych oraz ich mieszaniny z osadami koksowniczymi nie różniły się od siebie więcej niż o $25 \%$. Zatem osady koksownicze mogą być unieszkodliwiane w procesie fermentacji wraz z osadami komunalnymi pod warunkiem stałej kontroli jakościowo-ilościowej osadów i parametrów technologicznych.

Słowa kluczowe: biogaz, kofermentacja, osady ściekowe, osady ze ścieków koksowniczych 


\section{Introduction}

The anaerobic biological stabilization is currently the most common process of neutralizing sewage sludge in large wastewater treatment plants. Mineralization of biodegradable organic substrates is followed by an improvement of the drainage efficiency and a decrease of pathogenic organisms. The composition of fermented substrate depends on the quantity of the produced biogas and its composition. The content of methane in biogas varies from 50 up to $80 \%$ and depends on the content of proteins, carbohydrates and fats in sewage sludge subjected to the fermentation. In addition to the type of substrate, the fermentation process also depends on temperature, $\mathrm{pH}$, process duration, presence of toxic substances, substratum load chambers, concentration of easily digestible components for micro-organisms and appropriate conditions of their development $[1,2]$. Combustion of biogas allows for energy recovery. Therefore, produced biogas is used above all for the needs of covering demand for thermal energy and electricity. It is used for the needs of sewage treatment plants, such as heating digesters or powering devices for mixing and aerating $[3,4]$. Taking into account the need to develop effective treatment methods of excess sewage sludge from treated coking wastewater, studies on the co-fermentation of this sewage sludge with municipal sewage sludge were conducted. An aim of these studies was to assess the effect of excess sewage sludge from treated coking wastewater on the technological parameters of fermentation, mineralization degree of organic compounds and biogas production.

\section{Experimental procedure}

\subsection{Fermentation process}

Sewage sludge coming from municipal sewage treatment plant and sewage sludge from coking sewer plant were used in the study. Primary sewage sludge and excess sewage sludge as well as the fermented sewage sludge were collected. Primary sewage sludge and excess sewage sludge from a primary and a secondary settle tank were collected, respectively. Fermented sewage sludge was collected from the fermentation chamber. The samples were collected as temporary. In the coking wastewater treatment plant, the sewage treatment is performed by the processes of denitrification and nitrification. The sewage flows through a gravel filter, tar separator, and desorption column before it is fed to the biological part of the treatment plant and is directed to the averaging tank. The excess sewage sludge with treatment wastewater coking was sampled as temporary (from recycled tank of sewage sludge). The anaerobic digestion (fermentation) tests were conducted in bioreactors fitted with nozzles intended for measuring biogas pressure. The following mixtures were prepared for the fermentation studies:

- municipal sewage sludge (mixture of primary sewage sludge and excess sewage sludge with the addition of fermented sewage sludge $(1: 1.5 \mathrm{v} / \mathrm{v})$ as an inoculum) - control sample (K);

- municipal sewage sludge amended with excess sewage sludge from treated coking wastewater $(10: 1 \mathrm{v} / \mathrm{v})$ - sample (B). 
The sewage sludge mixtures were incubated for 16 days with no access to light in a thermostat at a constant temperature of $37 \pm 2^{\circ} \mathrm{C}$. The fermentation process was carried out in glass reactors with a volume of $1 \mathrm{~L}$ with a single power supply. The volume of sewage sludge was $0.7 \mathrm{~L}$. The process was carried out in 6 reactors with the same mixture of sewage sludge. After 4, 8, 12 and 16 days, one reactor was eliminated and a necessary analysis was conducted. The process was completed in 16 days because the amount of secreted biogas was difficult to measure with a manometer.

\subsection{Analytical methodology}

In order to determine the follow of the digestion process, the selected physical-chemical properties of the sewage sludge were determined. The total suspended solids (TSS) and fixed suspended solids (FSS) of the sewage sludge before and after 4, 8, 12 and 16 days of incubation were analyzed. In the supernatants, the $\mathrm{pH}$, alkalinity, chemical oxygen demand (DCOD) and volatile fatty acids (VFA) were determined. The above mentioned analyze were carried out before of the digestion process and after 4, 8, 12 and 16 days of samples incubation. The determinations were made in accordance with the methodology specified by Hermanowicz [5].

During the process, the atmospheric pressure and biogas pressure using the manometer in 24-hour intervals were monitored. The daily biogas volume using the Boyle-Mariott was calculated. The methane and carbon dioxide contents in biogas were determined four times. The analysis of biogas composition was performed using a gas chromatograph with a thermalconduction detector (GC-TCD) (model Agillent GC 6890).

\section{Results and discussion}

\subsection{Changes in the physico-chemical properties of sewage sludge during the fermentation process}

The results of the physical-chemical analysis of sewage sludge during 16 days of stabilization are shown in Table 1.

In test sludge $(\mathrm{K})$, there was a decrease in the contents of the total suspended solids by $21 \%$. The share of organic matter in sludge after 16 days of incubation constituted $54 \%$ of the dry mass. Decomposition degree of organic matter was $29 \%$. The contents of organic compounds determined as DCOD in supernatants from municipal sewage sludge $(\mathrm{K})$ decreased by $88 \%$.

In a mixture of municipal sewage sludge with industrial, the contents of dry matter before co-digestion process was $18.4 \mathrm{~g} / \mathrm{L}$. After the co-digestion process, there was a decrease in dry matter content by $18 \%$ (Table 2). Percentage of organic matter in fermented sludge was $54 \%$. Decomposition degree of organic matter was $23 \%$. The loss of organic compounds expressed with DCOD in supernatants was at a level of $81 \%$. 
Table 1. Changes in the physico-chemical properties of sewage sludge during the fermentation process - control sample

\begin{tabular}{|c|c|c|c|c|c|c|}
\hline \multirow{2}{*}{ Ratio } & \multirow{2}{*}{ Unit } & \multicolumn{6}{|c|}{ Process time, day } \\
\cline { 3 - 7 } & & 0 & 4 & 8 & 12 & 16 \\
\hline $\mathrm{pH}$ & - & 7 & 7.6 & 7.6 & 7.7 & 7.8 \\
\hline DCOD & $\mathrm{mg} \mathrm{O}_{2} / \mathrm{L}$ & 970 & 660 & 320 & 241 & 110 \\
\hline $\begin{array}{c}\text { Total suspended solids } \\
\text { (TSS) }\end{array}$ & $\mathrm{g} / \mathrm{L}$ & 18.9 & 17.6 & 16.9 & 16.2 & 15.0 \\
\hline $\begin{array}{c}\text { Fixed suspended solids } \\
\text { (FSS) }\end{array}$ & $\mathrm{g} / \mathrm{L}$ & 7.5 & 7.2 & 7.1 & 7.1 & 6.9 \\
\cline { 2 - 7 } & $\%$ & 40 & 41 & 42 & 44 & 46 \\
\hline $\begin{array}{c}\text { Volatile suspended solids } \\
\text { (VSS) }\end{array}$ & $\mathrm{g} / \mathrm{L}$ & 11.4 & 10.4 & 9.7 & 9.1 & 8.1 \\
\cline { 2 - 7 } & $\%$ & 60 & 59 & 58 & 56 & 54 \\
\hline
\end{tabular}

Table 2. Changes in the physico-chemical properties of sewage sludge during the co-fermentation process

\begin{tabular}{|c|c|c|c|c|c|c|}
\hline \multirow{2}{*}{ Ratio } & \multirow{2}{*}{ Unit } & \multicolumn{5}{|c|}{ Process time, day } \\
\hline & & 0 & 4 & 8 & 12 & 16 \\
\hline $\mathrm{pH}$ & - & 7.3 & 7.6 & 7.7 & 7.8 & 7.6 \\
\hline DCOD & $\mathrm{mg} \mathrm{O}_{2} / \mathrm{L}$ & 1300 & 940 & 400 & 390 & 240 \\
\hline $\begin{array}{c}\text { Total suspended solids } \\
\text { (TSS) }\end{array}$ & $\mathrm{g} / \mathrm{L}$ & 18.4 & 16.4 & 16.2 & 16.0 & 15.1 \\
\hline \multirow{2}{*}{$\begin{array}{l}\text { Fixed suspended solids } \\
\text { (FSS) }\end{array}$} & $\mathrm{g} / \mathrm{L}$ & 7.9 & 7.5 & 7.4 & 7.2 & 7.0 \\
\hline & $\%$ & 43 & 46 & 46 & 45 & 46 \\
\hline \multirow{2}{*}{$\begin{array}{l}\text { Volatile suspended solids } \\
\text { (VSS) }\end{array}$} & $\mathrm{g} / \mathrm{L}$ & 10.5 & 8.9 & 8.8 & 8.8 & 8.1 \\
\hline & $\%$ & 57 & 54 & 54 & 55 & 54 \\
\hline
\end{tabular}

The VFA ratio to alkalinity was shown in Figure 1 . The alkalinity after fermentation, determined in supernatants, was 3.55 and $3.50 \mathrm{~g} \mathrm{CaCO}_{3} / \mathrm{L}$ appropriately in the $\mathrm{K}$ and the $\mathrm{B}$ sample. The ratio of volatile fatty acids to alkalinity, decreased during the process, and after the process in test sludge, it was 0.11 . In a mixture of municipal sewage sludge with excess sewage sludge from treated coking wastewater, the value of the VFA quotient to alkalinity did not exceed 0.90 .

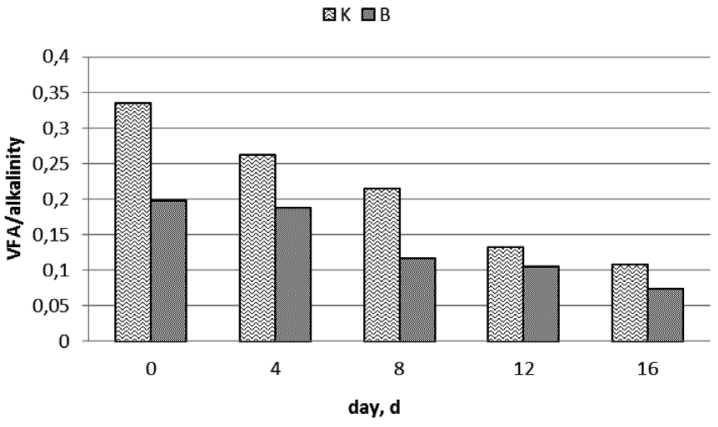

Fig. 1. The ratio of VFA to alkalinity 


\subsection{Biogas and methane production during the fermentation and co-fermentation processes}

The amount of biogas produced during each day of fermentation was presented in Table 3. In municipal sewage sludge $(\mathrm{K})$, the highest biogas production was achieved on the $3^{\text {rd }}$ day $(1.4 \mathrm{~L})$, whereas in the mixture of municipal sewage sludge with excess sewage sludge from treated coking wastewater, it was achieved on the $4^{\text {th }}$ day and it was $1.2 \mathrm{~L}$. This might show that there is a temporary interruption of the co-digestion process (elongated lag-phase) in the presence of industrial sewage sludge. Total biogas production ranged from $0.94 \mathrm{~L} / \mathrm{g}$ VSS $(1.0 \mathrm{~L})$ up to $1.03 \mathrm{~L} / \mathrm{g}$ VSS $(11.7 \mathrm{~L})$ and the average methane content in biogas was between $61-69 \%$. The amount of methane in relation to the contents of test sludge (K) was at the level of $8.1 \mathrm{~L}$. About $28 \%$ less $(5.9 \mathrm{~L})$ compared with test sludge was received during co-digestion of mixtures of municipal sewage sludge with excess sewage sludge from treated coking wastewater.

Table 3. Daily as well as total biogas and methane production during the fermentation and co-fermentation processes

\begin{tabular}{|c|c|c|c|c|c|c|c|c|}
\hline $\begin{array}{c}\text { Sewage sludge/ } \\
\text { Unit }\end{array}$ & \multicolumn{8}{|c|}{ Process time, day } \\
\hline $\mathrm{K}$ & 1 & 2 & 3 & 4 & 5 & 6 & 7 & 8 \\
\hline$\sum L^{a)}$ & 1.3 & 2.7 & 4.1 & 5.4 & 6.4 & 7.3 & 8.2 & 8.9 \\
\hline$\sum L^{b)}$ & 1.0 & 2.0 & 3.0 & 4.0 & 4.7 & 5.3 & 5.9 & 6.4 \\
\hline \multirow{2}{*}{$\mathrm{K}$} & \multicolumn{8}{|c|}{ Process time, day } \\
\hline & 9 & 10 & 11 & 12 & 13 & 14 & 15 & 16 \\
\hline$\sum \mathrm{L}^{\mathrm{a})}$ & 9.5 & 10.0 & 10.6 & 10.9 & 11.1 & 11.4 & 11.6 & 11.7 \\
\hline$\Sigma L^{b)}$ & 6.8 & 7.1 & 7.4 & 7.6 & 7.8 & 7.9 & 8.0 & 8.1 \\
\hline \multirow{2}{*}{ B } & \multicolumn{8}{|c|}{ Process time, day } \\
\hline & 1 & 2 & 3 & 4 & 5 & 6 & 7 & 8 \\
\hline$\sum \mathrm{L}^{\mathrm{a})}$ & 1.0 & 2.1 & 3.2 & 4.4 & 5.3 & 6.1 & 6.8 & 7.3 \\
\hline$\Sigma L^{b)}$ & 0.6 & 1.2 & 1.9 & 2.6 & 3.1 & 3.5 & 3.9 & 4.3 \\
\hline \multirow{2}{*}{ B } & \multicolumn{8}{|c|}{ Process time, day } \\
\hline & 9 & 10 & 11 & 12 & 13 & 14 & 15 & 16 \\
\hline$\sum \mathrm{L}^{\mathrm{a})}$ & 7.8 & 8.3 & 8.8 & 9.1 & 9.3 & 9.6 & 9.8 & 10.0 \\
\hline$\Sigma \mathrm{L}^{\mathrm{b})}$ & 4.6 & 4.9 & 5.2 & 5.4 & 5.5 & 5.6 & 5.8 & 5.9 \\
\hline
\end{tabular}

a) total production of biogas

b) total production of methane 
Basic co-digestion parameters of municipal sewage sludge with excess sewage sludge from treated coking wastewater were presented in Table 4. The load of digesters was in a range of $0.40-0.55 \mathrm{~g}$ VSS/L $\mathrm{d}$. The difference between maximum methane production $\left(V_{\max }\right)$ and the actual obtained value after 16 days was determined during fermentation. Its value corresponded numerically to the value of methane potential, residual in sewage sludge and changed in a range from 1.0 up to $1.5 \mathrm{~L}$. Favorable results were obtained during co-digestion of municipal sewage sludge, where untapped methane potential constituted 10\%. In studies conducted by Montusiewicz, the untapped biogas potential in sewage sludge ranged from 11.6 up to $14.1 \%$ [6].

During the fermentation process of municipal sewage sludge, as well as with excess sewage sludge from treated coking wastewater, the constant rate of generated methane ranged from 0.111 up to $0.147 \mathrm{~d}^{-1}$. In studies conducted by Myszograj, constant rates for excess sludge ranged from 0.179 up to $0.203 \mathrm{~d}^{-1}$, and for bio-fraction of municipal waste, they ranged from 0.077 up to $0.137 \mathrm{~d}^{-1}[7]$. Both during co-digestion of municipal sewage sludge with excess sewage sludge from treated coking wastewater or with bio-fraction of municipal sewage sludge, the constant rates were on the same level.

Table 4. Parameters and the energy balance of the co-fermentation process

\begin{tabular}{|l|c|c|c|}
\hline \multicolumn{1}{|c|}{ Parameters } & Unit & $\mathrm{K}$ & $\mathrm{B}$ \\
\hline Load of organic compounds in the fermentation chambers & $\mathrm{g}$ VSS $/ \mathrm{L}$ & 0.55 & 0.40 \\
\hline Percentage of the organic substance decomposition & $\%$ & 29 & 23 \\
\hline \multirow{2}{*}{ Production of biogas during digestion process } & $\mathrm{L}$ & 11.7 & 10.0 \\
\cline { 2 - 4 } & $\mathrm{L} / \mathrm{g}$ TSS & 0.62 & 0.54 \\
\cline { 2 - 4 } & $\mathrm{L} / \mathrm{g}$ VSS & 1.03 & 0.94 \\
\hline Content of methane in biogas on average & $\%$ & 61 & 63 \\
\hline \multirow{2}{*}{ Production of methane during digestion process } & $\mathrm{L}$ & 8.1 & 5.9 \\
\cline { 2 - 4 } & $\mathrm{L} / \mathrm{g}$ TSS & 0.43 & 0.39 \\
\cline { 2 - 4 } & $\mathrm{L} / \mathrm{g}$ VSS & 0.71 & 0.68 \\
\hline \multirow{2}{*}{ The maximal (theoretical) methane production (Vmax) } & $\mathrm{L}$ & 9.1 & 7.4 \\
\cline { 2 - 4 } & $\mathrm{L} / \mathrm{g}$ TSS & 0.48 & 0.40 \\
\cline { 2 - 4 } & $\mathrm{L} / \mathrm{g}$ VSS & 0.80 & 0.70 \\
\hline The potential of methane remaining in sewage sludge & $\%$ & 10 & 20 \\
\hline Constant rate of the methane production, $\mathrm{k}$ & $\mathrm{d}^{-1}$ & 0.147 & 0.111 \\
\hline Nonlinear estimation error & $\mathrm{L}$ & 0.14 & 0.16 \\
\hline Coefficient of determination, R & - & 0.995 & 0.975 \\
\hline
\end{tabular}


In the assumed test conditions of technological parameters of sewage sludge fermentation and its mixtures with sewage sludge, cokes did not differ from each other by more than $25 \%$ (total biogas productions, decomposition degree of organic matter, changes in the content of organic compounds expressed with DCOD, loss of dry matter and methane content in biogas).

Literature data show that, during mesophilic fermentation, the VFA concentration should be in the range from 50 to $500 \mathrm{mg} \mathrm{CH} \mathrm{CHOH}_{3} \mathrm{~L}$; alkalinity should be from 3.00 to $5.00 \mathrm{~g}$ $\mathrm{CaCO}_{3} / \mathrm{L}$, while the reduction in $\mathrm{COD}$ should be within the limits of $65-85 \%$, and $\mathrm{pH}$ value should be within the limits of 7.2-8.2 $[8,9]$.

Studies conducted by Fukas-Płonka et al. showed that the loss of dry matter of sewage sludge in the fermentation process was $18 \%$, and the decomposition degree of organic matter was at the level of $22 \%$. Total biogas production was $2.5 \mathrm{~L}$, while the amount of produced biogas from $1 \mathrm{~g}$ VSS entered into the reactor was at the level $0.18 \mathrm{~L} / \mathrm{g}$ VSS. During fermentation of excess sludge, the total quantity of biogas was $1.2 \mathrm{~L}$, which, expressed in the amount of dry organic matter, was $0.07 \mathrm{~L} / \mathrm{g}$ VSS. The loss of organic compounds did not exceed $15 \%$ [10]. In other studies, in which preliminary sewage sludge was the research material, the concentration of volatile fatty acids in fermented sewage sludge fluctuated from 467 to $664 \mathrm{mg} \mathrm{CH}_{3} \mathrm{COOH} / \mathrm{L}$, and the alkalinity from 3.24 to $3.51 \mathrm{~g} \mathrm{CaCO}_{3} / \mathrm{L}$. The quotient of VFA/alkalinity was in a range from 0.14 up to 0.19 . The loss of dry matter ranged from 20 to $28 \%$, and organic matter from 28 to $35 \%$ [11].

In Borowski et al. studies, the loss of organic dry substance in excess sludge was recorded in the range from 23.7 to $43.0 \%$, and the amount of biogas per organic dry matter unit was on average $0.3 \mathrm{~L} / \mathrm{g}$ VSS. During the fermentation of preliminary sludge, the decomposition degree of organic matter was $38 \%$, and the amount of biogas in relation to $1 \mathrm{~g}$ VSS was $0.27 \mathrm{~L} / \mathrm{g}$ VSS $[12,13]$.

In earlier studies of authors published in the Annual Set The Environment Protection [14], a mixture of municipal sludge and excess sludge was subjected to co-digestion from coke waste treatment. Sewage sludge samples were collected in the winter season. DCOD value in supernatants decreased by $47 \%$ in fermentation of municipal sludge. Biogas production for sludge unit volume from test sludge was $4.6 \mathrm{~L}$, and the amount of produced biogas per $1 \mathrm{~g}$ VSS was $0.47 \mathrm{~L} / \mathrm{g}$ VSS. After the co-digestion process of a mixture of municipal sludge and coke, the decomposition degree of organic substances was $22 \%$, and organic compounds expressed with DCOD rate amounted to $44 \%$. The total amount of biogas from sludge unit volume for mixtures of municipal sludge with coke was $4.0 \mathrm{~L}$, while the amount of biogas produced from $1 \mathrm{~g}$ VSS entered into the reactor was at the level of $0.31 \mathrm{~L} / \mathrm{g}$ VSS [14].

The described studies were conducted in similar conditions, but excess coke sewage sludge was collected in the summer season in the process of modernization of the coking battery. In this case, decomposition of organic compounds, both for municipal sludge and that involving coke, expressed with the DCOD rate, was 2-fold higher than in the winter season. In addition, the amount of biogas was higher during the digestion of sewage sludge collected in the summer season. Therefore, it is possible to state that the concentration of easily biodegradable compounds was higher in sewage sludge collected in the summer season 
than the concentration of these compounds in sewage sludge collected in winter, readily biodegradable, resulting in greater amount of biogas compared to sewage sludge in the winter period. During the modernization of the coking battery, the production of coke was smaller, and simultaneously the concentration of toxic compounds was smaller, including polycyclic aromatic hydrocarbons (PAHs) in coke sewage sludge. This explains the production of a larger amount of biogas in the co-digestion process.

In studies on the fermentation of excess sludge conducted by Bohdziewicz et al., the removal degree of organic matter was $44.5 \%$, and quotient of VFA/alkalinity -0.1 [15]. Biogas production during fermentation of excess sludge was $0.30 \mathrm{~L} / \mathrm{g}$ VSS, and the percentage of methane in biogas ranged from 51.3 to $72.0 \%$. After the stabilization process, the biodegradation degree, determined on the basis of COD in excess sludge, was $41 \%$ [7].

Due to the loss of organic compounds, biogas production, and organic matter in fermented sludge, it is possible to state that municipal sewage sludge and mixture excess sewage sludge from treated coking wastewater were fermented well, since the values of studied sewage sludge parameters after the process were in a range given by other authors.

\section{Conclusions}

Based on the conducted studies, it is possible to present the following conclusions:

- Co-digestion of sewage sludge with excess sewage sludge from treated coking wastewater cannot exceed the mixing ratio of 10:1. While maintaining the above proportions, the technological parameters of sewage sludge fermentation and its mixtures with sewage sludge coke did not differ from each other by more than $25 \%$ (total biogas productions, decomposition degree of organic matter, changes in the content of organic compounds expressed with DCOD, loss of dry matter and methane content in biogas).

- Excess sewage sludge from treated coking wastewater can be neutralized in the fermentation process along with municipal sewage sludge provided that there is a constant quality-quantitative control of the sewage sludge and technological parameters. However, in order to confirm the above, it is necessary to conduct the study in a flow system.

Research was supported by BS-BP-402-301/11.

\section{References}

[1] SadeckaZ., Toksycznośćw procesie beztlenowej stabilizacji komunalnych osadówściekowych, Monografie nr 105, Polska Akademia Nauk, Komitet Inżynierii Środowiska, Zielona Góra 2013.

[2] Podedworna J., Umiejewska K., Technologia osadów ściekowych, Oficyna Wydawnicza Politechniki Warszawskiej, Warszawa 2008. 
[3] Bień J., Wystalska K., Osady Ściekowe. Teoria i praktyka, Wydawnictwo Politechniki Częstochowskiej, Częstochowa 2011.

[4] Sidełko R., Chmielińska-Bernacka A., Zastosowanie reaktora kompaktowego do fermentacji metanowej odpadów komunalnych, Annual Set The Environment Protection $15,2013,683-693$.

[5] Hermanowicz W., Dojlido J., Dożańska W., Koziorowski B., Zerbe J., Fizyczno-chemiczne badanie wody i ścieków, Arkady, Warszawa 1999.

[6] Montusiewicz A., Wspótfermentacja osadów ściekowych i wybranych kosubstratów jako metoda efektywnej biometanizacji, Polska Akademia Nauk, Komitet Inżynierii Środowiska 98, Lublin 2012.

[7] Myszograj S., Biochemical Methane Potential as Indicator of Biodegradability of Organic Matter in Anaerobic Digestion Process, Annual Set The Environment Protection 13, 2011, $1245-1260$.

[8] Kardos L., Juhasz A., Palko GY., Olah J., Barkacs K., Zaray GY., Comparing of mesophilic and thermophilic anaerobic fermented sewage sludge based on chemical and biochemical tests, Applied Ecology and Environmental Research, 9, 2011, 293-302.

[9] Álvarez A.A., Otero L., Lema J.M., A methodology for optimising feed composition for anaerobic co-digestion of agro-industrial wastes, Bioresource Technology 101, 2010, $1153-1158$.

[10] Fukas-Płonka Ł., Janik M., Fermentacja osadów nadmiernych, EkoTechnika, 1, 2006, $52-56$.

[11] Janosz-Rajczyk M., Dąbrowska L., Rosińska A., Płoszaj J., Zakrzewska E., Zmiany ilościowo-jakościowe PCB, WWA i metali ciężkich $w$ kondycjonowanych osadach ściekowych stabilizowanych biochemicznie, Wydawnictwo Politechniki Częstochowskiej, Częstochowa 2006.

[12] Borowski S., Domański J., Ocena procesu kofermentacji mieszaniny pomiotu kurzego, organicznej biomasy roślinnej i osadów ściekowych, Ekologia i Technika, 4, 2009, 182-186.

[13] Borowski S., Domański J., Kofermentacja pomiotu kurzego z osadami ściekowymi, Ekologia i Technika, 3, 2012, 192-196.

[14] Macherzyński B., Włodarczyk-Makuła M., Ocena możliwości unieszkodliwiania osadów koksowniczych $w$ procesie kofermentacji, Annual Set The Environment Protection, 17, 2015, 1142-1161.

[15] Bohdziewicz J., Kuglarz M., Kofermentacja bioodpadów komunalnych i osadów ściekowych, Ochrona Środowiska i Zasobów Naturalnych, 38, 2009, 36-43. 


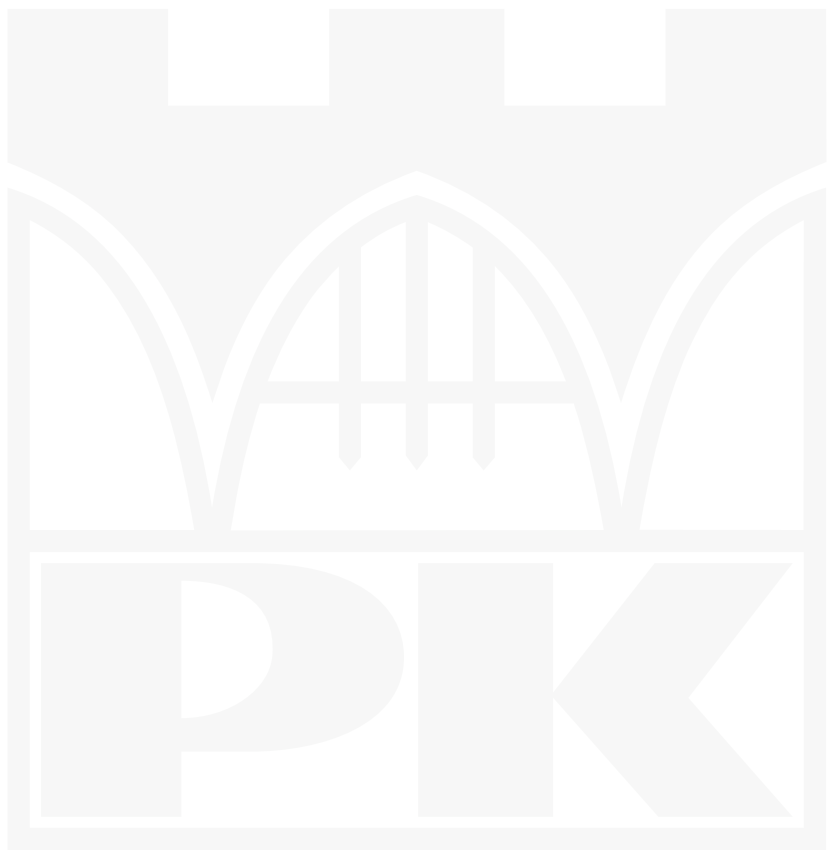

